\title{
Wadi Cultivation: A Promising Approach towards Improving Livelihood and Nutritional and Livelihood Security in Tribal Areas of Chhattisgarh Plain, India
}

\author{
Vinamarta Jain ${ }^{1}$, Abhay Bisen ${ }^{1 *}$, Krishnakant Rajak ${ }^{2}$ and Divedi Prasad ${ }^{1}$ \\ ${ }^{1}$ SKS College of Agriculture and Research Station, Rajnandgaon, \\ IGKV (Chhattisgarh), India \\ ${ }^{2}$ SRF, Farmers FIRST Project, SKSCARS, Rajnandgaon, IGKV (Chhattisgarh), India \\ *Corresponding author
}

\section{Keywords}

Wadi, Livelihood,

Vegetables,

Farmers,

Intervention,

Rainfed, Irrigated

\section{Article Info}

Accepted:

07 September 2019

Available Online:

10 October 2019

\section{A B S T R A C T}

Wadi cultivation is a major programme of socio-economic rehabilitation of the tribals and other backward sections throughout the country. Wadi is not only a programme for providing food security and ecological restoration but it is also a strong foundation to build the local capabilities to initiate other community development programmes for socio-economic development and has relevance for all sections of the society feasible with ecological restoration with poverty eradication. Kitchen garden or backyard cultivation is locally known as wadi cultivation in Chhattisgarh. The area of wadi ranged from 0.10 to 1.00 acre with average of 0.56 acre and using for cultivation of vegetables and fruit plants. Wadi cultivation has tremendous potential for improving livelihood of smallholders. Mostly vegetable is grown and utilizing for domestic purposes but enterprising farmers are growing vegetables for selling purposes. In this study, 62 wadis were randomly selected respectively from Murltitola, Arajkund, Kaudikasa, Bhagwantola and Netamtola villages of Rajnandgaon district 2016-17 with objectives to promote this practice as enterprise for earning of the farm families after systematic economic analysis and policy support. Weekly input and output of Wadi cultivation was recorded from 62 farmers during 2016-17, thereafter, critical inputs like hybrid vegetable seed, irrigation and skill development on vegetable production were given (2016-17 to 201718) to the farmers as interventions for promoting productivity and assessing potential of the system. After two years, data were collected and analyzed and presented here with reference to baseline done in 2016-17. Major crops grown by the farmers were tomato, brinjal, cowpea, cauliflower, cabbage, coriander, chilli, bitter guard, lady finger, spinach, bottle guard, onion potato, radish, ginger and turmeric. The wadi area was divided for 2-4 crops in a season by the farmers depending on availability of resources and market. Significant improvement in vegetable yields was recorded before 2016-17 and after 2017-18 interventions. Annual net income from each Wadi system ( 0.48 acre) was Rs.39231 before intervention and Rs. 72395 after intervention under rainfed condition. Farmers (based on average of 62 farmers) were getting Rs. 130461 and Rs. 275610 before (2016-17) and after (2017-18) interventions under irrigation condition. The cropping intensity increased from 132 to 160 percent under rainfed condition whereas, under irrigated condition, the intensity improved from 236 to 270 percent. Farmers were harvesting produce daily and transporting throw cycles or motor cycles for selling in the local market. Thus, it can be concluded that the Wadi system is very attractive economically and nutritionally for survival and sustaining livelihoods of rural smallholder. 


\section{Introduction}

Kitchen gardening is one of the world's most ancient food production practices and is practiced throughout the world. Kitchen gardening or backyard cultivation is common in India. Wadi cultivation has tremendous potential for improving livelihood of smallholders. In Chhattisgarh, some area is left behind mostly back or either side of the house and used for cultivation of vegetables. This space is also used for other domestic requirements like cleaning utensils, bathing, keeping agriculture equipment's, fuel and animal drinking water (Hooza, 2004). The excess water after use was diverted to wards vegetables that grow without extra care and no separate time devoted for management and produced shall act as supplement in family food (Nichols and Hilmi, 2009). The Wadi production of fruit and vegetable provides the households with direct access to important nutrients that may not be readily available or within their economic reach. The Wadi model of tribal development is holistic in approach addressing production, processing and marketing of the produce and also other livelihood needs Kirtimani and Selvan (2016). This study was undertaken with objectives to promote this practice as enterprise for earning of the farm families after systematic economic analysis and policy support.

\section{Materials and Methods}

The technological intervention was undertaken in rural area of Rajnandgaon district of Chhattisgarh plain to investigate the role of Wadi cultivation in addressing food security. The research used both qualitative and quantitative approach to collect data from household and stakeholders. Stratified samples are used to pick household respondents. The demonstration module was conducted in five villages of Ambagarhchowki namely Murltitola, Arajkund, Kaudikasa,
Bhagwantola and Netamtola during 2016-17 and 2017-18 in Kharif - Rabi and Zaid season. Twelve to thirteen families from each village were selected randomly making total of 62 participants. Different capacity building activities trainings, exposure visit, farmers science interaction on various aspect of vegetable cultivation were undertaken.

The farmers of the adopted villages were advised about planning a Wadi in scientific and organic way that all the seasonal vegetables could be grown fresh and thus available round the year. Use of high yielding varieties of different vegetable and few plants of nutritious fruits like ten plants of papaya, five plants of munga, four plants of banana were also planted in Wadi. The size of Wadi was designated to be big enough to produce sufficient vegetables for the family $(0.50$ acre).

\section{Results and Discussion}

\section{Percentage of farmers involved in size bases Wadi cultivation}

In the study area average size of Wadi was 0.56 acre. Before intervention majority of farmers (46\%) possessing 0.10 to 0.25 acre Wadis whereas $26 \%$ were cultivating 0.25 0.50 acre size of Wadis. After intervention tribal farmers $(50 \%)$ possessing 0.10 to 0.25 acre Wadis in 2017-18 (Table 1). Size of Wadi's was increasing probably due to increasing prospects of Wadi cultivation to better income. These results are in conformity with the findings of Rathore et al., (2016)

\section{Wadi cultivation and vegetable crops grown in around year}

During rainy season farmer prefer to grown 2 vegetable crops under rainfed condition whereas 2-3 vegetables were grown by the farmers under irrigated condition in the same 
piece of land. Rainfed Wadis were 0.72 acre in size before intervention that further reduced to 0.70 acre after intervention indicating that size of rainfed Wadis are gradually reducing and converting to irrigated Wadis (Table 2). Before 2016-17, 15.4 percent Wadis were rainfed but some of the farmers created irrigation as intervention of the project and only $6.8 \%$ Wadis remained rainfed at the end of 2017-18 (After two years). During Rabi season 1-2 crops were taken by the farmers under rainfed condition where as 2-3 crops were common under irrigated condition (Jiterwal, 2008). Size of Wadi cultivation decreased during Rabi season both under rainfed and irrigated conditions. With availability of irrigation Wadi cultivation were also done by the farmers during summer season in limited area by growing 2-3 crops in same piece of land. These results corroborate the findings of Arya et al., (2018).

\section{Vegetables grown under rainfed and irrigated conditions}

More than twenty vegetables were growing by the farmers in the study area. The name of vegetables is tomato, brinjal, cowpea, cauliflower, cabbage, coriander, chilli, bitter guard, okra, spinach, bottle guard, onion, radish, and other leafy vegetables. Preference of the vegetables was different both under rainfed and irrigated conditions and size of wadi also. Allocation of area to each selected vegetables also varied according to water availability. Cowpea and bitter-gourd were the most popular vegetables amongst the farmers. Sponge gourd, cabbage, cauliflower, bitter gourd, tomato, okra, coriander and cowpea preferred more under irrigation condition.

\section{Economic returns and cropping intensity}

Area of Wadi was increased 129 and 117 percent after intervention compared to start of the project respectively under rainfed and irrigated conditions during Kharif season. This increase during Rabi season was 134 and 112 percent respectively before and after interventions in rainfed and irrigated conditions respectively. Increase in area was $167 \%$ after intervention than before start of the project during summer season under irrigated condition. Similar findings have been made by Chayal et al., (2013) and Pandya (1988).In general gross and net income increased remarkably during the three years in all the seasons (Table 3).

On average farmer were obtaining gross income of Rs. 60293/- per wadi before start of the project which was recorded Rs. 151627/after intervention (2017-18) during rainy season under rainfed condition Net income per wadi increased from Rs.43098/- to 70208/- as impact of the project interventions during rainy season under irrigated condition. During Rabi season, gross income increased from Rs. 68746 to 170872 /- per wadi as impact of the project. Net income increased from Rs. 27782 to $70813 /$ - per wadi as impact of the intervention under irrigated condition (Table $3)$.

During summer season, the increase in gross and net income was respectively from Rs. 121755 to $250935 /-$ and 59581 to $135489 /-$. Similar results were reported by Tandel et al., (2014) and Phansalkar and Verma (2005).

Total size of wadi in three cropping seasons, increased from 0.94 to 1.23 acre under rainfed and from 1.85 to 2.37 acre under irrigated condition annually. From Wadi, annually gross income of farmer increased from Rs. 77573 to 192525 under rainfed and Rs. 313867 to 724818 under irrigated condition while net income enhanced from Rs. 39231 to 72395 under rainfed and from Rs. 130461 to 276510 under irrigated condition (Table 3). Similar results were reported by Nandal and Vashist (2009). 
Table.1 Percentage of farmers involved in Wadi cultivation

\begin{tabular}{|c|c|c|c|c|}
\hline \multirow{2}{*}{$\begin{array}{l}\text { Size of Wadi } \\
\quad \text { (acre) }\end{array}$} & \multicolumn{2}{|c|}{ Before intervention(2016-17) } & \multicolumn{2}{|c|}{ After intervention (2017-18) } \\
\hline & $\begin{array}{l}\text { Average area } \\
\text { (acre) }\end{array}$ & $\begin{array}{l}\text { Percent farmers } \\
\qquad(\mathrm{N}=62)\end{array}$ & $\begin{array}{l}\text { Average area } \\
\text { (acre) }\end{array}$ & $\begin{array}{l}\text { Percent farmers } \\
\qquad(\mathrm{N}=62)\end{array}$ \\
\hline 0.1-0.25 & 0.18 & 45.9 & 0.23 & 50.3 \\
\hline $0.25-0.50$ & 0.35 & 25.8 & 0.44 & 28.4 \\
\hline 0.5-0.75 & 0.60 & 15.1 & 0.70 & 16.4 \\
\hline $0.75-1.0$ & 0.80 & 13.1 & 0.90 & 4.9 \\
\hline Average & 0.48 & & 0.56 & \\
\hline
\end{tabular}

Table.2 Average size of Wadi and number of crops grown during the three growing seasons of vegetables in adopted villages cluster

\begin{tabular}{|c|c|c|c|c|c|c|}
\hline \multirow[t]{2}{*}{ Particulars } & \multicolumn{3}{|c|}{ Before intervention (2016-17) } & \multicolumn{3}{|c|}{ After intervention (2017-18) } \\
\hline & $\begin{array}{l}\text { Rainfed } \\
(\mathrm{N}=20)\end{array}$ & $\begin{array}{c}\text { Tube } \\
\text { well } \\
(\mathrm{N}=20)\end{array}$ & Total & $\begin{array}{l}\text { Rainfed } \\
(\mathrm{N}=20\end{array}$ & $\begin{array}{c}\text { Tube } \\
\text { well } \\
(\mathrm{N}=20)\end{array}$ & Total \\
\hline \multicolumn{7}{|c|}{ Rainy season (June-Nov) } \\
\hline $\begin{array}{c}\text { No. of vegetables } \\
\text { grown }\end{array}$ & 2.57 & 3.25 & 2.91 & 2.24 & 4.86 & 3.55 \\
\hline Average area (acres) & 0.52 & 0.80 & 0.76 & 0.50 & 1.16 & 0.98 \\
\hline \multicolumn{7}{|c|}{ Rabi season(Nov-Feb) } \\
\hline $\begin{array}{l}\text { No. of vegetables } \\
\text { grown }\end{array}$ & 1.74 & 2.11 & 1.92 & 1.19 & 2.84 & 2.01 \\
\hline Average area (acres) & 0.63 & 0.68 & 0.65 & 0.52 & 0.82 & 0.67 \\
\hline \multicolumn{7}{|c|}{ Summer season(Feb-May) } \\
\hline $\begin{array}{l}\text { No. of vegetables } \\
\text { grown }\end{array}$ & & 2.46 & 2.46 & & 3.15 & 3.15 \\
\hline Average area (acres) & & 0.48 & 0.48 & & 0.68 & 0.68 \\
\hline \multicolumn{7}{|l|}{ Overall annually } \\
\hline $\begin{array}{l}\text { No. of vegetable } \\
\text { grown }\end{array}$ & 2.15 & 2.68 & 2.43 & 1.71 & 3.61 & 2.90 \\
\hline Average area (acres) & 0.57 & 0.65 & 0.63 & 0.51 & 0.98 & 0.84 \\
\hline
\end{tabular}


Table.3 Economics and cropping intensity of Wadi cultivation before (2016-17) and after (201718) interventions at adopted villages under the project

\begin{tabular}{|c|c|c|c|c|c|c|c|}
\hline Season & Ecological & $\begin{array}{l}\text { Period } \\
\text { of data }\end{array}$ & $\begin{array}{c}\text { Area } \\
\text { (Acres) }\end{array}$ & $\begin{array}{c}\text { Gross } \\
\text { return (Rs. } \\
\text { per badi) }\end{array}$ & $\begin{array}{l}\text { Net return } \\
\text { (Rs. per } \\
\text { badi) }\end{array}$ & $\begin{array}{c}\text { Employment } \\
\text { (man days } \\
\text { per badi) }\end{array}$ & $\begin{array}{c}\text { Cropping } \\
\text { intensity } \\
(\%)\end{array}$ \\
\hline \multirow{4}{*}{$\begin{array}{c}\text { Rainy } \\
\text { season } \\
\text { (June-Nov) }\end{array}$} & \multirow[t]{2}{*}{ Rainfed } & Before & 0.62 & 60293 & 30821 & 48 & \\
\hline & & After & 0.80 & 15687 & 55586 & 75 & \\
\hline & \multirow[t]{2}{*}{ Irrigated } & Before & 0.78 & 114366 & 53098 & 65 & \\
\hline & & After & 0.92 & 175595 & 70208 & 102 & \\
\hline \multirow{4}{*}{$\begin{array}{c}\text { Rabi } \\
\text { season } \\
\text { (Nov- } \\
\text { Feb) }\end{array}$} & \multirow[t]{2}{*}{ Rainfed } & Before & 0.32 & 17290 & 8410 & 35 & \\
\hline & & After & 0.43 & 40898 & 16809 & 51 & \\
\hline & \multirow[t]{2}{*}{ Irrigated } & Before & 0.58 & 68746 & 27782 & 58 & \\
\hline & & After & 0.65 & 170872 & 70813 & 78 & \\
\hline \multirow{2}{*}{$\begin{array}{c}\text { Summer } \\
\text { season } \\
\text { (Feb- } \\
\text { May) }\end{array}$} & \multirow[t]{2}{*}{ Irrigated } & Before & 0.48 & 121755 & 59581 & 42 & \\
\hline & & After & 0.80 & 250935 & 135489 & 80 & \\
\hline \multirow{4}{*}{$\begin{array}{c}\text { Annual } \\
\text { total }\end{array}$} & \multirow[t]{2}{*}{ Rainfed } & Before & 0.94 & 77573 & 39231 & 83 & 132.1 \\
\hline & & After & 1.23 & 192525 & 72395 & 126 & 159.1 \\
\hline & \multirow[t]{2}{*}{ Irrigated } & Before & 1.85 & 304867 & 130461 & 165 & 235.7 \\
\hline & & After & 2.37 & 597402 & 276510 & 260 & 269.9 \\
\hline
\end{tabular}

Cropping intensity increased from 132 to 160 percent under rainfed and from 236 to 270 percent under irrigated condition. Importance of kitchen gardening were also reported by IIHR (2016), Vijayalakshmi and Thooyavathy (2012) for nutritional and livelihood security of smallholders.

\section{References}

Arya, S., S. Prakash, S. Joshi, K.M Tripathi and V. Singh. 2018. Household foo security through kitchen gardening in rural areas of western uttar pradesh, India. Int.J.Curr.Microbiol.App.Sci. 7(2):468-474.

Chayal, K., B.L. Dhaka, M.K.Poonia and R.K. Bairawa. 2013. Improving nutritional security through kitchen gardening in rural areas. Asian Journal of Home Science 8(2): 607-609.
Hooza, M. 2004. Policies and strategies for tribal development: focus on the central tribal belt, Rawat Publications, New Delhi, India.

IIHR. 2016. Backyard nutritional kitchen gardening-A success story. http://www.iihr.res.in/content/backyar $d$-nutritional-kitchen-gardeningsuccess-story.

Jiterwal, R.C. 2008. Impact of drip irrigation technology among farmers in Jaipur region of Rajasthan. Ph.D. Thesis, Rajasthan Agricultural University, Bikaner, Campus, Jobner, Rajasthan, India.

Kirtimani Tripati and Thiru Selvan. 2016. Identification of training needs of rural females in improved home and farm managerial practices in western Uttarpradesh. Journal of Community Mobilization and Sustainable Development 11 (1): 24-28 
Nichols, M. and M. Hilmi. 2009. Growing vegetables for home and market. Rural Infrastructure and Agro-Industries Division Food and Agriculture Organization of the United Nations Rome. $\quad h t t p: / / w w w$.fao.org/3/ai0526e.pdf.

Nandal, J.K. and S. Vashisth. 2009. Sustainable household food security through nutrition gardens. Proceeding International Conference Horticulture, pp. 1966-1967.

Pandya, A. 1988. Rethinking marketing's role in development. Marketing and economic development: Issues and opinions. proceedings of the second international conference on marketing and development, Karl marx university of economics sciences. Budapest, Hungary, PP. 1009-1012.
Phansalkar, S.J. and S. Verma. 2005. Mainstreaming the margins: water centric livelihood strategies for revitalizing tribal agriculture in central India, Angus and Grapher, New Delhi, India. pp. 187-192.

Rathore, S.K., A.L.Rathore, R.L.Sharma and B.Sahu 2016. Evaluation of Wadi Cultivation for nutritional and livelood security of small holders. Progressive Research Journal 11 (2):127-131.

Tandel, B.M., Y.N.Tandel, R.M. Naik and C.K Timbadiya. 2014. Wadi : A boon for sustainable livelihood. Agric. Update, 9(2): 204-206.

Vijayalakshmi, K. and R. Thooyavathy. 2012. Nutritional and health security through integrated gardens: The Ciks experience. Universitas Forum, 3(1) http://www.universitasforum.org /index.php/ojs/index.

\section{How to cite this article:}

Vinamarta Jain, Abhay Bisen, Krishnakant Rajak and Divedi Prasad. 2019. Wadi Cultivation: A Promising Approach towards Improving Livelihood and Nutritional and Livelihood Security in Tribal Areas of Chhattisgarh Plain. Int.J.Curr.Microbiol.App.Sci. 8(10): 817-822.

doi: https://doi.org/10.20546/ijcmas.2019.810.094 